\title{
Desiccation, dormancy, and storage of Pterocarya fraxinifolia (Juglandaceae) seeds: application in Hyrcanian and Colchian forest conservation
}

\author{
Mikołaj Krzysztof Wawrzyniak, Anna Katarzyna Jasińska, Paweł Chmielarz, and Gregor Kozlowski
}

\begin{abstract}
Pterocarya fraxinifolia (Poir.) Spach (Juglandaceae) is a model relict tree species native to South Caucasus and is a typical element of threatened riparian forests. Intensive land transformations, which are common in Transcaucasia, have resulted in loss of natural habitat and population decline of the species. One of the methods of ex situ conservation is seed banking. Cryopreservation in liquid nitrogen $\left(-196^{\circ} \mathrm{C}\right)$ is of particular interest, as it allows safe preservation of valuable plant genetic resources. However, the feasibility of seed cryopreservation is related to the desiccation tolerance and intrinsic composition of the seeds. In this study, we examined the physiological traits of Pterocarya fraxinifolia seeds, for which desiccation tolerance is unknown or controversial, and their feasibility for cryopreservation. Additionally, we tested stratification methods for dormancy assessment. Results showed that seeds survived desiccation to a moisture content of $2.8 \%$ with a germination rate of $64 \%$. Stratification at a temperature of $3{ }^{\circ} \mathrm{C}$ for 8 weeks proved to be both fast and effective. Seed moisture content ranging from $2.8 \%$ to $18.1 \%$ was determined to be safe for cryopreservation. There was no difference in seedling emergence in seeds stored for 1 year regardless of the storage temperature $\left(-3,-18\right.$, or $\left.-196^{\circ} \mathrm{C}\right)$. Based on our results, Pterocarya fraxinifolia seeds can be classified as orthodox. This study demonstrates for the first time the feasibility of cryopreserving Pterocarya fraxinifolia seeds.
\end{abstract}

Key words: seed banking, cryopreservation, biodiversity, critical moisture content, Georgia.

Résumé : Pterocarya fraxinifolia (Poir.) Spach (Juglandacées) est une espèce arborescente relique modèle originaire du Caucase du Sud et un élément typique des forêts riveraines menacées. D’importantes transformations du territoire, fréquentes en Transcaucasie, ont entraîné la perte d'habitats naturels et le déclin des populations de cette espèce. Une des méthodes de conservation ex situ consiste à avoir recours aux banques de semences. La cryoconservation dans l'azote liquide $\left(-196^{\circ} \mathrm{C}\right)$ est particulièrement intéressante parce qu'elle permet de conserver de façon sécuritaire les ressources génétiques d'espèces végétales précieuses. Cependant, la faisabilité de la cryoconservation des graines dépend de leur tolérance à la dessiccation et de leur composition intrinsèque. Dans cette étude, nous avons examiné les traits physiologiques des graines de Pterocarya fraxinifolia dont la tolérance à la dessiccation est inconnue ou controversée ainsi que la possibilité de les cryoconserver. De plus, nous avons testé des méthodes de stratification pour évaluer la dormance. Les résultats montrent que les graines ont survécu à la dessiccation jusqu’à une teneur en humidité de $2,8 \%$ avec un taux de germination de $64 \%$. La stratification à une température de $3{ }^{\circ} \mathrm{C}$ pendant huit semaines s'est avérée à la fois rapide et efficace. Une teneur en humidité des graines de 2,8 \% à 18,1 \% était sécuritaire pour la cryoconservation. Il n'y avait pas de différence dans l'émergence des semis issus de graines conservées pendant un an peu importe la température $\left(-3{ }^{\circ} \mathrm{C},-18^{\circ} \mathrm{C}\right.$, ou $\left.-196^{\circ} \mathrm{C}\right)$ à laquelle elles avaient été conservées. Sur la base de nos résultats, les graines de Pterocarya fraxinifolia peuvent être qualifiées d'orthodoxes. Cette étude démontre pour la première fois qu'il est possible de cryoconserver les graines de Pterocarya fraxinifolia. [Traduit par la Rédaction]

Mots-clés : création d’une banque de semences, cryoconservation, biodiversité, teneur en humidité critique, Géorgie.

\section{Introduction}

The conservation of plant genetic resources is an established and globally recognized priority because the variability of species is fundamental to forestalling their extinction. It is estimated that there are more than 300000 species of land plants, all of which are essential for the proper functioning of local ecosystems (Corlett 2016). However, many populations of plants are currently threatened by loss, fragmentation, and degradation of habitats, as well as overexploitation, invasive species, and climate change (Groom et al. 2005). Conservation programs for threatened species can follow a variety of criteria (i.e., economic value, ecological value, or species uniqueness). One of the unique and irreplaceable parts of the plant kingdom is relict trees. These surviving remnants have been present on the earth for millions of years, representing evolutionary processes and outlasting environmental, biogeographical, and climate changes. Despite their continued exis-

Received 7 December 2018. Accepted 15 September 2019.

M.K. Wawrzyniak and P. Chmielarz. Department of Reproduction Biology and Population Genetics, Institute of Dendrology, Polish Academy of Sciences, Parkowa 5, 62-035, Kórnik, Poland.

A.K. Jasińska. Laboratory of Systematics and Geography, Institute of Dendrology, Polish Academy of Sciences, Parkowa 5, 62-035, Kórnik, Poland. G. Kozlowski. Department of Biology, University of Fribourg, Chemin du Musée 10, CH-1700 Fribourg, Switzerland; Natural History Museum Fribourg, Chemin du Musée 6, CH-1700 Fribourg, Switzerland.

Corresponding author: Mikołaj Wawrzyniak (email: mikwaw@man.poznan.pl). 
tence over millions of years, they usually retain a narrow distribution in so-called refugia (Maharramova et al. 2017; Kozlowski et al. 2018) such as the Hyrcanian area of northern Iran. The unique ecosystems of Hyrcanian forests, as well as the plains around the Black Sea (Colchian forests), are one of the most valuable biosphere genetic resources in the world and shelter many relict species such as Parrotia persica (DC.) C.A. Mey., Gleditsia caspica Desf., Zelkova carpinifolia (Pall.) K. Koch, and Pterocarya fraxinifolia (Poir.) Spach (Naqinezhad et al. 2018).

In situ conservation has its limitations. A holistic approach to conservation is often difficult to fund and maintain (Diamond 1989); therefore, an ex situ conservation method such as seed banking seems to be most suitable for seed-bearing species, as it provides an inexpensive and effective long-term strategy (Bewley et al. 2013; Zaritzky 2015). The viability of stored seeds depends on the seed moisture content (MC) and storage temperature (Vertucci and Roos 1990). Seed storability at low temperature depends on the seed's desiccation tolerance, as excess water can crystallize and cause intracellular damage (Wesley-Smith et al. 2014). The practical categorization proposed by Roberts (1973) and then supplemented by Ellis et al. (1990) considers three categories of seeds based on their desiccation sensitivity: orthodox (seeds that tolerate desiccation below a 5\% MC, based on fresh mass), recalcitrant (seeds that do not tolerate desiccation), and intermediate (seeds that exhibit characteristics of both former categories (i.e., seeds that tolerate moderate desiccation but lose viability during subsequent storage at sub-zero temperatures)). However, careful study of seed physiology is important: seed storage behavior is often more complex, as cellular responses to water and temperature thresholds can result in desiccation sensitivities in between these categories (Walters 2015).

Cryopreservation in liquid nitrogen $\left(\mathrm{LN} ;-130\right.$ to $\left.-196{ }^{\circ} \mathrm{C}\right)$ represents a safe and cost-effective option for the long-term storage of germplasm. In recent years, cryopreservation has become a successful method for conserving unique (i.e., endemic, endangered, and economically valuable) species, both as vegetative tissues such as dormant buds and shoot tips and generative organs such as seeds and embryos (Engelmann 2011; Lambardi and Shaarawi 2017). For orthodox seed species, cryopreservation is an alternative to traditional storage at $-20^{\circ} \mathrm{C}$ and is of particular importance for long-term storage (tens to hundreds of years; Reed 2008); it is the only method for the long-term storage of intermediate and recalcitrant seed species. Cryopreservation of the seeds of woody species has proven to be effective for both orthodox and recalcitrant seeds in many tree species, including Alnus glutinosa (L.) Gaertn. (Chmielarz 2010a), Coffea L. spp. (Dussert et al. 1998), Prunus armeniaca L. (Malik and Chaudhury 2010), and Prunus padus L. (Popova et al. 2016). Together with the ex situ approach, cryopreservation has been successfully utilized in conservation programs for herbaceous plants such as Cosmos atrosanguineus (Hook.) Voss (Wilkinson 2003) and Lomandra sonderi (F.Muell.) Ewart (Menon et al. 2014). Cryopreservation, together with modern biotechnology, has been implemented in conservation programs for many national floras, including those of Brazil (Pilatti et al. 2011), Spain (González-Benito and Martín 2011), and Australia (Ashmore et al. 2011).

In our study, we examined Pterocarya fraxinifolia (Caucasian wingnut) of the walnut family (Juglandaceae) as a model relict tree species that belongs to the group of so-called Arcto-Tertiary relict trees and grows in the lowlands and riparian habitats of South Caucasus and Anatolia and the Caspian (Hyrcanian) forests of Iran, Georgia, Turkey, and Azerbaijan (Boratyński and Boratyńska 1975; Kozlowski et al. 2018). During the Oligocene and Miocene epochs, the species was widespread in the Northern Hemisphere, but because of climate cooling over the last 15 million years, it became restricted to southern refugial areas characterized by a more stable climate (Manchester 1987; Milne and Abbott 2002; Maharramova et al. 2017). In some locations, the population growth of the species depends on individual clonal reproduction via root sprouts, as natural regeneration via seeds is poor and the majority of the seeds are empty (up to 90\%; Yilmaz 2015). Pterocarya fraxinifolia populations are characterized by intermediate to low genetic diversity (Akhani and Salimian 2003; Yilmaz 2015; Maharramova et al. 2017; Yousefzadeh et al. 2018), and there is a danger that if the habitats of this species continue to degrade, it may - similar as in Alnus Mill. spp. and other riparian species (Barsoum et al. 2004; Dering et al. 2017) - lead to a significant increase in clonality. Although some of the populations are protected within national parks in Georgia, Azerbaijan, and Iran, more protection is necessary - especially considering edge and stand-alone populations - to preserve the genetic diversity of Pterocarya fraxinifolia (Kozlowski et al. 2018). In the scientific literature, there is a lack of comprehensive studies on Pterocarya fraxinifolia seed traits (storage behavior, desiccation tolerance, and dormancy) regarding the preservation of genetic diversity. Pterocarya fraxinifolia seeds have physiological dormancy, and Çiçek and Tilki (2008) found that the release of Pterocarya fraxinifolia seeds requires at least 5 weeks of cold stratification in $4{ }^{\circ} \mathrm{C}$ without a medium, as seeds in control treatments did not germinate without stratification. However, no detailed studies on dormancy release for seeds from natural stands have been conducted, and information about dormancy in other species of Pterocarya Kunth is sparse and indeterminate. According to the Seed Information Database (Royal Botanic Gardens Kew 2008), Pterocarya fraxinifolia seeds are considered to be orthodox, despite the lack of information on their desiccation tolerance at $<5 \% \mathrm{MC}$ and storage viability in sub-zero temperatures. General knowledge of storage behavior in the Juglandaceae family is understudied and sometimes outdated. It is crucial to understand seed traits of these species to develop and implement long-term methods of conservation (i.e., cryopreservation); however, seed tolerance to storage at low (subzero) temperatures $\left(-3,-18\right.$, and $\left.-196^{\circ} \mathrm{C}\right)$ is unknown for Pterocarya fraxinifolia. The aim of the present study was to examine the biological traits of Pterocarya fraxinifolia seeds, including their desiccation tolerance, dormancy type, and tolerance to sub-zero temperatures, to establish an effective method for the conservation of the species' genetic resources. More specifically, we examined (i) the critical moisture content (CMC) of Pterocarya fraxinifolia seeds, (ii) the high moisture freezing limit (HMFL) for cryopreserved seeds, (iii) stratification methods (with and without a medium), and (iv) the viability of the seeds after 1 year of storage at three different temperatures $\left(-3,-18\right.$, and $\left.-196^{\circ} \mathrm{C}\right)$.

\section{Materials and methods}

\section{Collection and MC}

Mature fruits of Pterocarya fraxinifolia were collected in September 2016 from 20 individual trees growing along Ninoskhevi River ( $\geq 20 \mathrm{~m}$ from each other) in Ninigori, Eastern Georgia (South Caucasus, $41^{\circ} 49^{\prime} 52^{\prime \prime} \mathrm{N}, 46^{\circ} 12^{\prime} 28^{\prime \prime} \mathrm{E}$ ), and were transferred to the lab. The semi-orbicular wings were wiped off with sand during cleaning, and all remaining impurities were removed using sieves. Seeds were collected dry and had an initial MC of $11.5 \%$. The term "nutlet" used in this paper refers to the true fruit of Pterocarya fraxinifolia (the central part of the fruit, with a hard pericarp that is enclosed in the fleshy, green tissue issued from the fused floral elements, mainly the bracteoles) (Figs. 1A and 1B; Schaarschmidt 2006). MC was determined separately for (i) the nutlet, containing the seed and pericarp, and (ii) the seed only. However, for practical reasons, the seed MC used throughout this paper applies to the nutlets. The MC (\%) was calculated based on fresh mass using the following formula:

$$
\mathrm{MC}_{1}=\frac{\left(\mathrm{FM}_{1}-\mathrm{DM}\right) \times 100}{\mathrm{FM}_{1}}
$$


Fig. 1. (A) Illustration of Pterocarya fraxinifolia (a) fruit and (b) nutlet and $(c)$ a longitudinal section of a nutlet with a seed inside. (B) A seedling emerging from a nutlet, $(C)$ a seedling, and (D) a 1-year-old seedling planted from a cryopreserved seed. [Color online.]

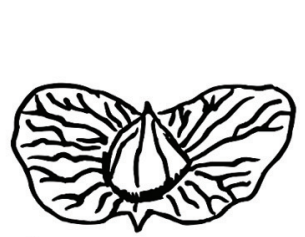

a)

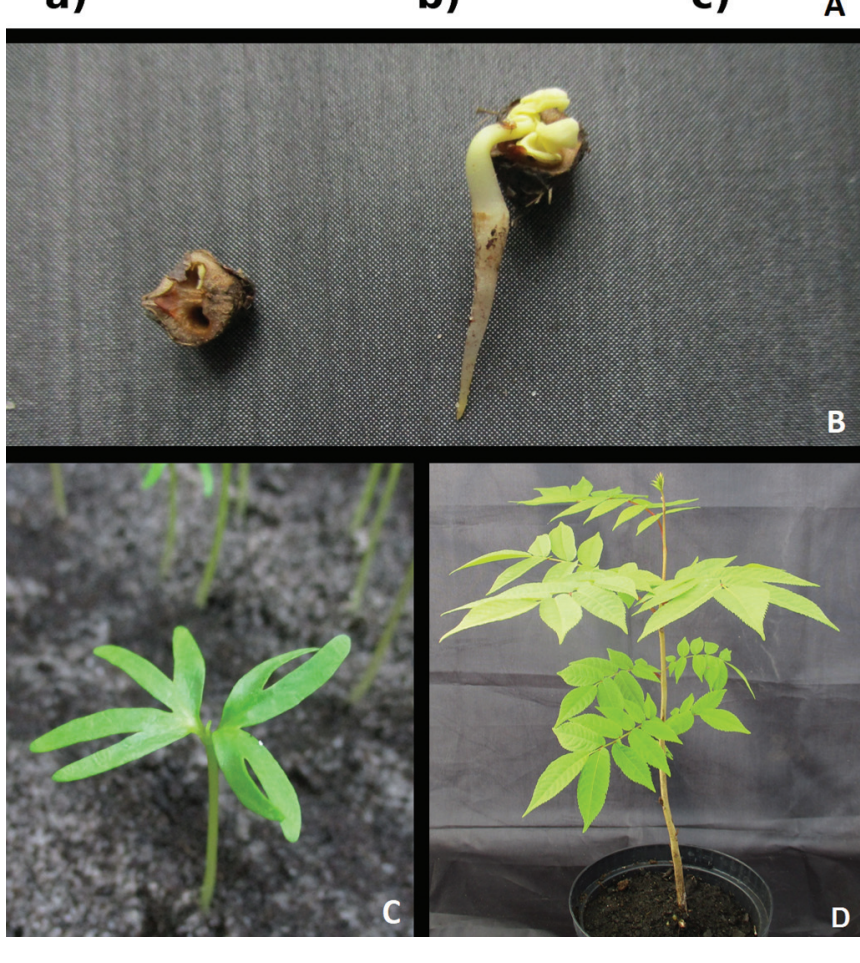

where $\mathrm{MC}_{1}$ is the moisture content, $\mathrm{FM}_{1}$ is the initial fresh mass, and DM is the dry mass after drying.

The MC of the nutlets used for cryopreservation was adapted (either by drying or moisturizing) to obtain 10 levels of MC ranging from $3 \%$ to $30 \%$, with increments of approximately $3 \%$. Nutlets with MC $>10 \%$ were moisturized several times with water to obtain a higher MC, up to $30 \%$. A lower MC was obtained after desiccation over activated silica gel. Adjusting the MC of the nutlets was based on the FM of the moisturized or desiccated seeds according to the following formula:

$$
\mathrm{FM}_{2}=\frac{\mathrm{FM}_{1} \times\left(100-\mathrm{MC}_{1}\right)}{100-\mathrm{MC}_{2}}
$$

where $\mathrm{FM}_{2}$ is the desired mass and $\mathrm{MC}_{2}$ is the desired moisture content. After obtaining the desired $\mathrm{MC}$, the nutlets were left in tightly closed containers for $3-5$ days at $3{ }^{\circ} \mathrm{C}$ to even out the MC.

After reaching the mass of the desired MC level, the exact MC was determined by drying the nutlets at $103 \pm 2{ }^{\circ} \mathrm{C}$ for $17 \mathrm{~h}$ (three replicates of 10 nutlets). Seed CMC was determined by a germination test of the lowest level of tested MC (2.3\%). HMFL was set for the highest seed MC that tolerated cryopreservation.

\section{Stratification and germination test}

To break the dormancy of the seeds, the Pterocarya fraxinifolia nutlets underwent cold stratification at $3{ }^{\circ} \mathrm{C}$ after storage. In our experiment, we used five different stratification methods to determine the most sufficient method that could be later used in a cryopreservation experiment: (A) 12 weeks at $3{ }^{\circ} \mathrm{C}$ in a stratification medium; (B) 8 weeks at $3{ }^{\circ} \mathrm{C}$ in a stratification medium; (C) 12 weeks at $3{ }^{\circ} \mathrm{C}$ without a stratification medium after moisturizing the nutlets up to $40 \% \mathrm{MC}$; (D) 12 weeks at $3{ }^{\circ} \mathrm{C}$ without a stratification medium, soaking the seeds for $1 \mathrm{~h}$ once per week and, after 4 weeks of stratification, soaking the seeds every 2 weeks; and (E) submergence in LN for $48 \mathrm{~h}$ and stratification for 12 weeks at $3^{\circ} \mathrm{C}$.

The stratification medium used in our experiment was a moist mixture $(\mathrm{v} / \mathrm{v}, 1: 1)$ of sieved peat $(\mathrm{pH} 3.5-4.5)$ and quartz sand fraction $(<1 \mathrm{~mm})$. Stratification without a substrate occurred in plastic boxes with a lid. The seeds in method $C$ were soaked in tap water for $1 \mathrm{~h}$. Then, the water was drained from the boxes and the moist seeds were covered with a lid and kept inside the box. Subsequently, the box with wet seeds was placed at $3{ }^{\circ} \mathrm{C}$. The moisture of the stratification medium and the visual condition of the nutlets were checked once per week regardless of the stratification method used.

The stratification medium was mixed with the nutlets in a 3:1 ratio and placed in $25 \mathrm{~mL}$ plastic bottles with a lid. Each lid had three $0.5 \mathrm{~cm}$ diameter holes allowing gas exchange. The conditions of the nutlets and the substrate were monitored once per week to avoid soil drying.

The seed germination test for all experiments was performed after stratification in the same soil substrate as previously described. The germination test was conducted in darkness, with the temperature cyclically alternating between 3 and $20^{\circ} \mathrm{C}(16$ and $8 \mathrm{~h}$ per day, respectively). Once per week, the germinated seeds were counted and discarded. After 10 weeks, the remaining nutlets were cut to examine seed viability.

A seedling emergence test was also conducted in the same soil mixture of peat and sand that was used in the germination test. After stratification, the nutlets were sown in plastic boxes into the substrate at a depth of $1 \mathrm{~cm}$ and covered with a layer of sand. To avoid severe drying of the substrate, the boxes were covered with a transparent plastic lid. The seedling emergence test was conducted under the same thermal conditions as the germination test ( 3 and $20^{\circ} \mathrm{C}, 16$ and $8 \mathrm{~h}$ per day, respectively) until the seedling reached ca. $2 \mathrm{~cm}$ in height. Then, the boxes with the seedlings were moved into the light ( $60 \mu \mathrm{mol} \cdot \mathrm{m}^{-2} \cdot \mathrm{s}^{-1}$ for $8 \mathrm{~h}$ per day) in a chamber with a controlled temperature of $20^{\circ} \mathrm{C}$. The experiment investigating seed cryopreservation and storage time consisted of three replications per 30 nutlets, and the experiment evaluating the best stratification method consisted of four replications per 50 nutlets.

\section{Cryopreservation and storage}

Before freezing (at $-196{ }^{\circ} \mathrm{C}$ ), the nutlets were placed in a plastic bag, which was tightly sealed. The material was frozen by direct immersion in LN for $48 \mathrm{~h}$. Subsequently, plastic bags with the material were thawed at $42{ }^{\circ} \mathrm{C}$ in a water bath for $5 \mathrm{~min}$.

The nutlets were stored at temperatures of -3 and $-18{ }^{\circ} \mathrm{C}$ in $\mathrm{LN}$ for 2 weeks and for 1 year, with an $11.8 \% \mathrm{MC}$. The nutlets that were not stored were used as a control treatment.

\section{Statistical analyses}

Data were analyzed using $\mathrm{R}$ statistical computing software ( $R$ Core Team 2017). We used analysis of variance (ANOVA) to analyze significant differences between the mean values and Tukey's test for the pairwise comparisons. Mean values from each variant were calculated from three replicates of the seed sample. Each replicate was placed in a separate box and then randomly placed in an incubator or Dewar (one incubator per each temperature). Analyses were performed after Bliss transformation (arc sine) of the proportional data. We analyzed seed treatment used in each experiment as the fixed effect in a one-way ANOVA. For the cryo- 
Fig. 2. Germination rate of seeds after stratification methods A-E: (A) 8 weeks at $3^{\circ} \mathrm{C}$, (B) 12 weeks at $3{ }^{\circ} \mathrm{C}$, (C) 12 weeks at $3{ }^{\circ} \mathrm{C}$ without stratification medium and $40 \%$ seed moisture content, (D) 12 weeks at $3^{\circ} \mathrm{C}$ without stratification medium and periodically submerged in water, and (E) submerged in liquid nitrogen for $48 \mathrm{~h}$ and stratified for 12 weeks at $3^{\circ} \mathrm{C}$.

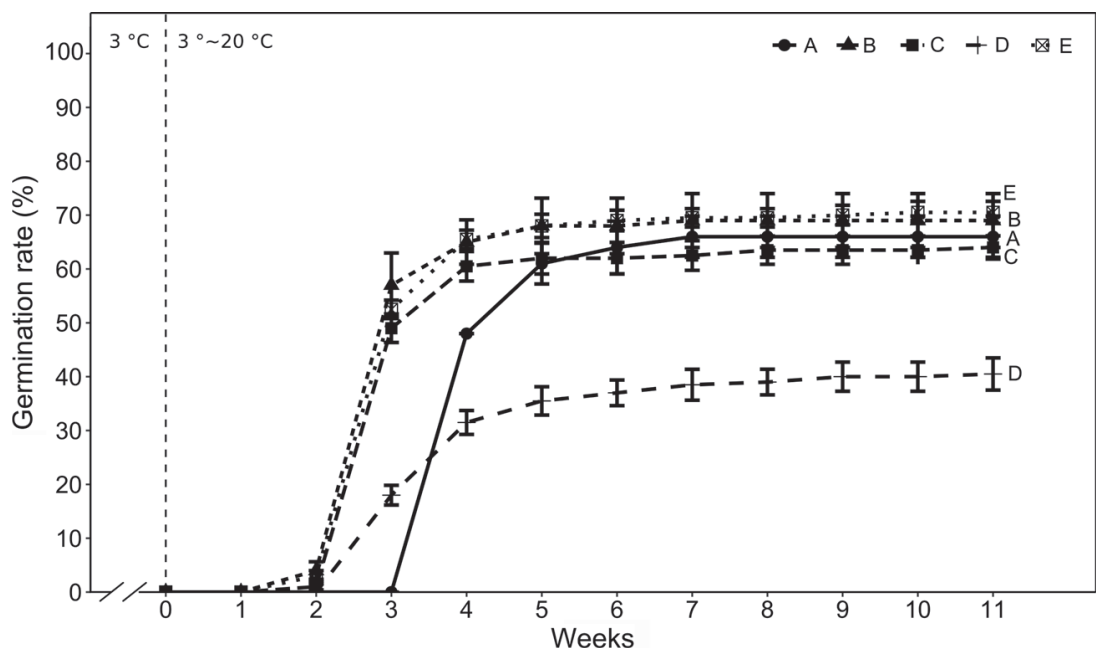

Table 1. Germination rate, percentage of empty nutlets, and percentage of viable but nongerminated seeds after different stratification methods at $3{ }^{\circ} \mathrm{C}$ : (A) 12 weeks; (B) 8 weeks; (C) 12 weeks without a stratification medium, without soaking; (D) 12 weeks without a stratification medium, with periodical soaking of seeds; and (E) submergence in liquid nitrogen and stratification for 12 weeks.

\begin{tabular}{cllc}
\hline Method & Germination (\%) & $\begin{array}{l}\text { Empty } \\
\text { nutlets (\%) }\end{array}$ & $\begin{array}{l}\text { Viable but } \\
\text { nongerminated } \\
\text { seeds (\%) }\end{array}$ \\
\hline A & $66.0 \pm 3.83 \mathrm{a}$ & $29.0 \pm 4.43$ & $5.0 \pm 1.91$ \\
B & $69.0 \pm 5.00 \mathrm{a}$ & $27.0 \pm 4.12$ & $4.0 \pm 1.63$ \\
C & $64.0 \pm 2.16 \mathrm{a}$ & $28.0 \pm 2.83$ & $8.0 \pm 0.82$ \\
D & $40.5 \pm 2.99 \mathrm{~b}$ & $22.5 \pm 2.22$ & $37.0 \pm 1.29$ \\
E & $70.5 \pm 2.06 \mathrm{a}$ & $25.0 \pm 1.73$ & $4.5 \pm 1.26$ \\
\hline
\end{tabular}

Note: Values are means \pm standard errors. Different lowercase letters denote significant differences between treatments $(P=0.05$, Tukey's test).

preservation experiment, we used a two-way ANOVA with integrations for MC level and LN treatment. ANOVAs and Tukey's tests were performed separately for the germination and emergence tests.

\section{Results}

\section{Seed MC, stratification, and germination}

The highest germination rate $(70.5 \%)$ was obtained after submerging the seeds in LN for $48 \mathrm{~h}$ prior to 12 weeks of cold stratification (method E; Fig. 2). Stratification for 12 weeks at $3{ }^{\circ} \mathrm{C}$ without a stratification medium and periodic submersion in water for moisturization resulted in a significantly lower germination rate of $40.5 \%$ and the highest number of decayed seeds $(37 \%$; method D; Table 1). The other tested methods of stratification (A, $\mathrm{B}$, and $\mathrm{C}$ ) showed similar results, with the germination rate varying between $64 \%$ and $69 \%$ (Table 1 ). For the following experiments, we used stratification for 8 weeks at $3^{\circ} \mathrm{C}$ (method B), as this method was both fast and efficient compared with the other methods tested. The exact MCs (both for the nutlet and the seed inside) used in the experiments are shown in Table 2.

\section{Tolerance to sub-zero storage}

The tested temperatures $\left(-3,-18\right.$, and $\left.-196{ }^{\circ} \mathrm{C}\right)$ had no significant effect on germination or seedling emergence after 1 year of storage (Fig. 3). The best results after 1 year of storage were ob-
Table 2. Moisture content (MC) of the nutlets and seeds used in the experiment.

\begin{tabular}{lcr}
\hline & \multicolumn{2}{l}{ MC (\%) } \\
\cline { 2 - 3 } Experiment & Nutlets & \multicolumn{1}{c}{ Seeds } \\
\hline After harvest & $11.8 \pm 0.05$ & $6.8 \pm 0.74$ \\
Stratification & & \\
$\quad$ Method D & $52.3 \pm 2.27$ & $26.6 \pm 1.96$ \\
Method C & $39.5 \pm 0.50$ & $22.4 \pm 1.08$ \\
Cryopreservation & & \\
Moisture level 1 & $2.8 \pm 0.03$ & $2.3 \pm 0.06$ \\
Moisture level 2 & $6.4 \pm 0.02$ & $4.1 \pm 0.11$ \\
Moisture level 3 & $9.2 \pm 0.12$ & $5.0 \pm 0.14$ \\
Moisture level 4 & $11.9 \pm 0.03$ & $5.8 \pm 0.07$ \\
Moisture level 5 & $15.2 \pm 0.11$ & $7.8 \pm 0.18$ \\
Moisture level 6 & $18.1 \pm 0.20$ & $9.8 \pm 0.18$ \\
Moisture level 7 & $20.8 \pm 0.12$ & $11.6 \pm 0.14$ \\
Moisture level 8 & $24.3 \pm 0.03$ & $13.6 \pm 0.21$ \\
Moisture level 9 & $27.6 \pm 0.40$ & $15.7 \pm 0.37$ \\
Moisture level 10 & $29.6 \pm 0.24$ & $17.4 \pm 0.31$ \\
\hline \multicolumn{2}{l}{ Note: Values are means \pm standard errors. MC in the } \\
stratification experiment was tested for methods without \\
medium (see Table 1). Ten different moisture levels (rang- \\
ing from 3\% to 30\%) were used to establish a safe range of \\
MC for cryopreservation.
\end{tabular}

tained for nutlets kept at $-3{ }^{\circ} \mathrm{C}(68 \%$ and $69 \%$ for germination and seedling emergence, respectively).

Optimal seed hydration window for cryopreserved nutlets

Seeds dried in nutlets to $2.8 \% \mathrm{MC}$ had a germination rate of $64 \%$ and a seedling emergence rate of $62 \%$; in comparison, in the control nutlets with a $9.2 \% \mathrm{MC}$, the germination rate was $71 \%$ and the seedling emergence rate was 64\% (Figs. 4 and 5). Therefore, no $\mathrm{CMC}$ was recorded. The germination of the seeds with a nutlet MC of $2.8 \%-18.1 \%$ submerged in $\mathrm{LN}$ varied from $58 \%$ to $70 \%$, depending on the MC level, and did not differ significantly from the germination of the seeds that were not treated with LN (63\%-76\%; Fig. 4). Seedling emergence was between $56 \%$ and $70 \%$ for the same range of nutlet MCs and did not differ significantly from seeds that were not treated with LN, which emerged at between 53\% and 64\% (Fig. 5). Nutlets with an MC > 18.1\% (20.8\%-29.6\%) did not withstand freezing in LN and did not germinate; therefore, the HMFL was established as $18.1 \%$ MC. 
Fig. 3. (A) Seed germination and (B) seedling emergence of Pterocarya fraxinifolia for nonstored seeds and seeds stored for 2 weeks and for 1 year at temperatures of $-3,-18$, and $-196^{\circ} \mathrm{C}$. Bars represent means from three replications, and error bars represent standard errors. Different lowercase letters denote significant differences between treatments ( $P=0.05$, Tukey's test).



Fig. 4. Germination of Pterocarya fraxinifolia seeds after drying or moisturizing the nutlets to 10 levels of moisture content (2.8\%-29.6\%), untreated (control) or treated for $48 \mathrm{~h}$ with liquid nitrogen (LN). Bars represent means from three replications, and error bars represent standard errors. An asterisk (*) indicates orthodox seeds. Different lowercase letters denote significant differences between treatments $(P=0.05$, Tukey's test).

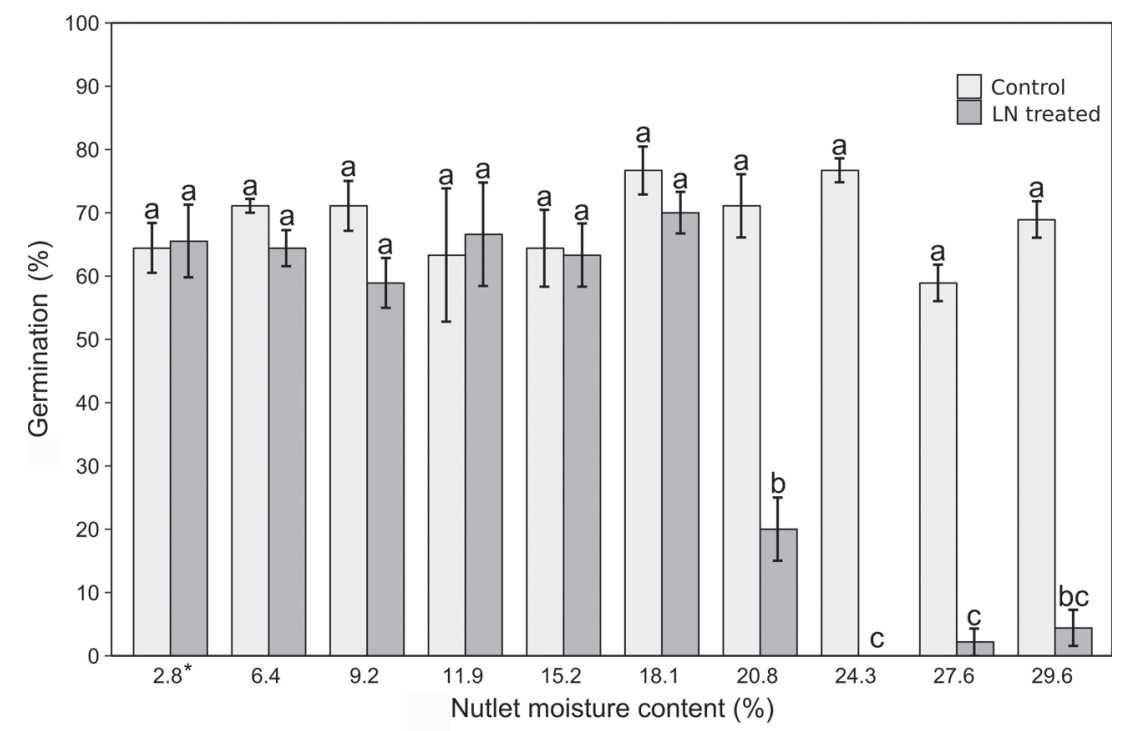

\section{Discussion}

Our study represents the first comprehensive assessment of the seed traits of Pterocarya fraxinifolia, from its natural stands in Transcaucasia, to determine the most appropriate ex situ conservation method for this important and endangered relict tree. We focused on seeds, examining their dormancy, storage behavior, desiccation tolerance, and feasibility for cryopreservation, which resulted in practical insights that are valuable for future conservation protocols.

\section{Seed dormancy, desiccation, and freezing tolerance}

Our study confirms that Pterocarya fraxinifolia seeds are characterized by endogenous, nondeep physiological dormancy, which can be overcome by 3 weeks of cold stratification at $4{ }^{\circ} \mathrm{C}$ (Çiçek and Tilki 2008). However, to maximize seed germination, 5-8 weeks of cold stratification is recommended, depending on the temperatures used during the germination process. In comparison, seeds of Pterocarya stenoptera C. DC. germinated at a rate of $16 \%$ without stratification, and the highest germination rate of $56 \%$ was recorded after just 3 weeks at $3{ }^{\circ} \mathrm{C}$. The prolongation of the cold period of stratification resulted in a decrease in germination (Grbić et al. 2011). In contrast, Wang et al. (2018) reported an $89 \%$ germination rate after 4 weeks of cold stratification for Pterocarya stenoptera seeds. Our study confirmed that the 12 weeks of stratification suggested by Young and Young (1992) can be shortened without a decrease in germination. The use of LN in pretreatment as a low-temperature factor promoting the permeability of the seed coat (Jastrzębowski et al. 2017) did not result in a significant increase in germination. In stratification without a medium, we suggest to not moisturize nutlets to an MC $>40 \%$ because it could result in seed decay (Table 1 ) and therefore lower the rate of germination. Our results indicate that in nursery practice, sowing nutlets after 8 weeks of cold stratification with or without medium would be most effective. 
Fig. 5. Emergence of Pterocarya fraxinifolia seedlings after drying or moisturizing the nutlets to 10 levels of moisture content (2.8\%-29.6\%), untreated (control) or treated for $48 \mathrm{~h}$ with liquid nitrogen (LN). Bars represent means from three replications, and error bars represent standard errors. Different lowercase letters denote significant differences between treatments $(P=0.05$, Tukey's test).

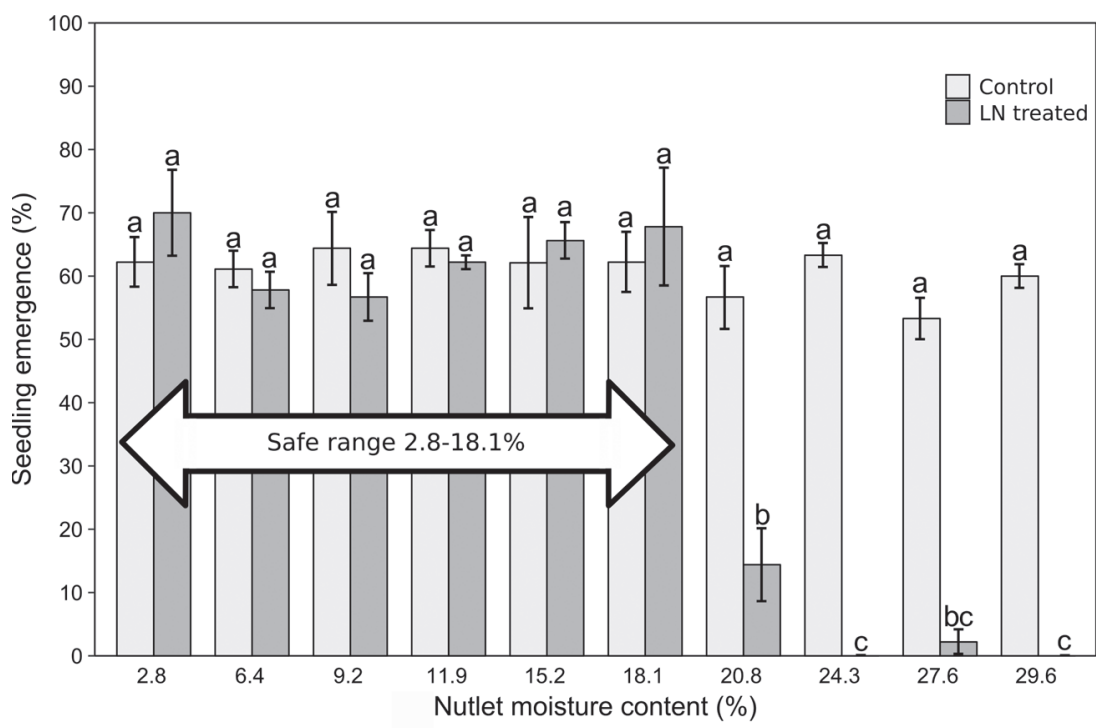

According to our results, the dormant seeds of Pterocarya fraxinifolia maintained high rates of germination and seedling emergence, even after strong desiccation of the nutlet to $2.8 \% \mathrm{MC}$; therefore, we did not record a CMC for this species. Moreover, the nutlets stored at sub-zero temperatures $\left(-3,-18\right.$, and $\left.-196{ }^{\circ} \mathrm{C}\right)$ remained viable after 1 year of storage. Based on these results, Pterocarya fraxinifolia seeds can be classified as orthodox seeds. Until now, the storage behavior of Pterocarya fraxinifolia seeds has never been clearly determined in the literature. In the Seed Information Database (Royal Botanic Gardens Kew 2008), Pterocarya fraxinifolia seeds are considered "likely orthodox", but some authors (Young and Young 1992) refer to safe storage for only for short periods of time without stating the proper MC or storage temperature. In some publications, Pterocarya fraxinifolia seeds are mistakenly classified as recalcitrant (Gordon and Rowe 1982; Grbić et al. 2011). These statements are based on only brief observations, and clarification is needed for the proper conservation of this species. In our research, Pterocarya fraxinifolia seeds were successfully stored at temperatures of $-3,-18$, and $-196{ }^{\circ} \mathrm{C}$ for 1 year at an MC level of $11.9 \%$, which suggests the possibility of long-term storage of the seeds in gene banks, both at traditionally used temperatures $\left(-18\right.$ or $\left.-20^{\circ} \mathrm{C}\right)$ and through cryopreservation. Seed viability after longer storage times still needs to be examined in the future.

Our work seems to confirm the results obtained for some other species of the Juglandaceae family. The majority of these trees appear to produce orthodox or intermediate seeds, although in the literature, evidence is often ambiguous. Gordon and Rowe (1982) recommended storing seeds of Juglandaceae spp. at approximately $15 \%$ of their $\mathrm{MC}$ and above $0{ }^{\circ} \mathrm{C}$, which is similar to the storage conditions for many intermediate seed species. McIlwrick et al. (2000) described Juglans cinerea L. seeds as recalcitrant, which do not survive desiccation below a $15 \%$ MC or storage below $-40{ }^{\circ} \mathrm{C}$. In general, seed behavior can differ among species within a specific family or even within a genus; for example, in the genus Acer L., most (but not all) of its member species produce orthodox seeds (Suszka et al. 1996). Sometimes differences in seed desiccation tolerance for a given species could be both geographical and taxonomical, as in species of the genus Araucaria Juss. (Tompsett 1983). One species of the genus Pterocarya with seeds confirmed for ex situ storage is Pterocarya macroptera Batalin, for which $89 \%$ of the viable seeds were stored at $15 \%$ relative humidity (ca. $5 \%$ seed MC) at $-20{ }^{\circ} \mathrm{C}$ for 1 month (Royal Botanic Gardens Kew 2008). In our study, we examined the viability of Pterocarya fraxinifolia seeds after 1 year at three different temperatures (including treatment with LN). Clear descriptions of storage behavior are crucial for conservation programs. Occasionally, data described in the literature can differ, as in the case of Carya illinoinensis (Wangenh.) K. Koch, which was previously thought to be a recalcitrant species (King and Roberts 1979) but was proven to be an orthodox species, surviving desiccation below 5.3\% MC (Bonner 1976; Dimalla and van Staden 1978; Goff et al. 1992).

\section{Feasibility of seed cryopreservation and nutlets storage}

We examined whether Pterocarya fraxinifolia seeds could be effectively cryopreserved when the nutlets were desiccated to an MC in a safe range of $2.8 \%-18.1 \%$ before storage in LN. A similar range of MC has been reported for some other orthodox species: Alnus glutinosa (2.7\%-19.2\%), Ulmus glabra Huds. (3.3\%-19.2\%), and Betula pendula Roth (2.0\%-23.2\%) (Chmielarz 2010a, 2010b, 2010c). However, some other riparian species, including Salix caprea L. (8.5\%-23.4\%; Popova et al. 2012) and Populus nigra L. (10\%-15\%; Michalak et al. 2015), have lower desiccation tolerances. The HMFL for these species is similar to our results for Pterocarya fraxinifolia (18.1\% MC; Fig. 5). We described for the first time the successful cryopreservation of seeds from the Juglandaceae family, although there are many previous reports of the effective cryopreservation of the embryo axes from species of the genera Juglans L. and Carya Nutt. (Pence 1990). Excised embryos of Juglans nigra L. can be cryopreserved for up to two decades without a significant loss of the initial viability (Ballesteros and Pence 2019). Seedling emergence in Pterocarya fraxinifolia did not differ when compared with germination, as occurred for Hippophae rhamnoides L. seeds (M. Wawrzyniak, personal communication), for which $\mathrm{LN}$-treated seeds at some MC levels germinated but failed to establish healthy seedlings.

Although there is still a lack of information about the long-term storage of Pterocarya spp. and most other species of Juglandaceae, our research shows that no damage occurs after 1 year of storage in LN (Figs. 1C and 1D). Thus, we assume that longer storage of Pterocarya fraxinifolia is possible. Temperatures of -3 and $-18{ }^{\circ} \mathrm{C}$, which are usually suggested for short- and long-term storage in gene-bank practice, also seem to be effective for Pterocarya fraxinifolia. Cryopreservation offers the most stable conditions for seed storage, potentially for hundreds of years (Pritchard et al. 2014). 


\section{Conclusions}

The seeds produced by Pterocarya fraxinifolia are classified as orthodox because they withstand desiccation below 5\% MC and can be stored at sub-zero temperatures for at least 1 year without losing viability. Based on our results, Pterocarya fraxinifolia seeds collected from natural endangered stands can be germinated after 8 weeks of cold stratification, resulting in seedlings 6-7 weeks after sowing. The safe range of $\mathrm{MC}$ allows for the effective storage of seeds in LN. Thus, cryopreservation can be implemented in conservation programs and protocols for this highly valuable relict tree species.

\section{Acknowledgements}

This work was supported by the Fondation Franklinia and the Institute of Dendrology, Polish Academy of Sciences, Kórnik, Poland (under statutory activity) (A.K.J., M.W., and P.C.). We thank two anonymous reviewers for their valuable comments, which greatly improved this manuscript.

\section{References}

Akhani, H., and Salimian, M. 2003. An extant disjunct stand of Pterocarya fraxinifolia (Juglandaceae) in the central Zagros Mountains, W Iran. Willdenowia, 33: 113-120. doi:10.3372/wi.33.33111.

Ashmore, S.E., Hamilton, K.N., and Offord, C.A. 2011. Conservation technologies for safeguarding and restoring threatened flora: case studies from Eastern Australia. In Vitro Cell. Dev. Biol. Plant, 47(1): 99-109. doi:10.1007/s11627-0109320-9.

Ballesteros, D., and Pence, V.C. 2019. Survival and growth of embryo axes of temperate trees after two decades of cryo-storage. Cryobiology, 88: 110-113. doi:10.1016/j.cryobiol.2019.04.005. PMID:31022387.

Barsoum, N., Muller, E., and Skot, L. 2004. Variations in levels of clonality among Populus nigra L. stands of different ages. Evol. Ecol. 18(5-6): 601-624. doi:10. 1007/s10682-004-5146-4.

Bewley, J.D., Bradford, K.J., Hilhorst, H.W.M., and Nonogaki, H. 2013. Seeds physiology of development, germination and dormancy. 3rd ed. Springer, New York. doi:10.1007/978-1-4614-4693-4.

Bonner, F.T. 1976. Storage and stratification recommendations for pecan and shagbark hickory. Tree Plant. Notes, 27: 3-5.

Boratyński, A., and Boratyńska, K. 1975. Geographical distribution of Pterocarya fraxinifolia Spach. Arbor. Kórnickie, 20: 131-138.

Chmielarz, P. 2010a. Cryopreservation of conditionally dormant orthodox seeds of Betula pendula. Acta Physiol. Plant. 32: 591-596. doi:10.1007/s11738-0090437-6.

Chmielarz, P. 2010b. Cryopreservation of orthodox seeds of Alnus glutinosa. CryoLetters, 31: 139-146. PMID:20687456.

Chmielarz, P. 2010c. Cryopreservation of the non-dormant orthodox seeds of Ulmus glabra. Acta Biol. Hung. 61: 224-233. doi:10.1556/ABiol.61.2010.2.10. PMID:20519176.

Ciçek, E., and Tilki, F. 2008. Influence of stratification on seed germination of Pterocarya fraxinifolia (Poiret) Spanch a relic tree species. Bot. Res. J. 3. doi:10. 3923/rjb.2008.103.106.

Corlett, R.T. 2016. Plant diversity in a changing world. Status, trends, and conservation needs. Plant Divers. 38: 10-16. doi:10.1016/j.pld.2016.01.001. PMID: 30159445.

Dering, M., Latałowa, M., Boratyńska, K., Kosiński, P., and Boratyńsk, A. 2017. Could clonality contribute to the northern survival of grey alder [Alnus incana (L.) Moench] during the Last Glacial Maximum? Acta Soc. Bot. Pol. 86(1): 3523. doi:10.5586/asbp.3523.

Diamond, J.M. 1989. Overview of recent extinctions. In Conservation for the twenty-first century. Edited by D. Western and M.C. Pearl. Oxford University Press, New York.

Dimalla, G.G., and van Staden, J. 1978. Pecan nut germination - a review for the nursery industry. Sci. Hortic. 8: 1-9. doi:10.1016/0304-4238(78)90063-8.

Dussert, S., Chabrillange, N., Engelmann, F., Anthony, F., Louarn, J., and Hamon, S. 1998. Cryopreservation of seeds of four coffee species (Coffea arabica, C. costatifructa, C. racemosa and C. sessiliflora). Importance of water content and cooling rate. Seed Sci. Res. 8: 199. doi:10.1017/S096025850000386X.

Ellis, R.H., Hong, T.D., and Roberts, E.H. 1990. An intermediate category of seed storage behaviour? J. Exp. Bot. 41: 1167-1174. doi:10.1093/jxb/41.9.1167.

Engelmann, F. 2011. Use of biotechnologies for the conservation of plant biodiversity. In Vitro Cell. Dev. Biol. Plant, 47(1): 5-16. doi:10.1007/s11627-0109327-2.

Goff, W.D., Brasher, L.R., and McGuire, J.A. 1992. Germination of unstratified pecans is affected by exposute to high temperature and by soaking. Sci. Hortic. 50: 159-163. doi:10.1016/S0304-4238(05)80019-6.

González-Benito, M.E., and Martín, C. 2011. In vitro preservation of Spanish biodiversity. In Vitro Cell. Dev. Biol. Plant, 47(1): 46-54. doi:10.1007/s11627010-9333-4.
Gordon, A.G., and Rowe, D.C.F. 1982. Seed manual for ornamental trees and shrubs. H.M.S.O., London.

Grbić, M., Skočajić, D., Obratov-Petković, D., Bjedov, I., Đjukic, M., and Đjunisijević-Bojović, D. 2011. Presowing treatments to breaking seed dormancy of Pterocarya stenoptera C. DC. as an indicator of potential invasiveness. Glas. Sumar. Fak. 103: 29-40. doi:10.2298/GSF1103029G.

Groom, M.J., Meffe, G.K.C., and Carroll, R. 2005. Principles of conservation biology. 3rd ed. Sinauer Associates, Sunderland, Mass.

Jastrzębowski, S., Ukalska, J., Kantorowicz, W., Klisz, M., Wojda, T., and Sułkowska, M. 2017. Effects of thermal-time artificial scarification on the germination dynamics of black locust (Robinia pseudoacacia L.) seeds. Eur. J. For. Res. 136: 471-479. doi:10.1007/s10342-017-1046-3.

King, M.W., and Roberts, E.H. 1979. The storage of recalcitrant seeds. Achievements and possible approaches: a report on a literature review carried out for the International Board for Plant Genetic Resources. FAO/IBPGR, Rome, Italy.

Kozlowski, G., Bétrisey, S., Song, Y.-G., Alvarado, E.V., Belchi, D., Boratyński, A., et al. 2018. Wingnuts (Pterocarya) and walnut family. Relict trees: linking the past, present and future. Natural History Museum Fribourg, Switzerland. pp. 127-135.

Lambardi, M., and Shaarawi, S. 2017. Importance of in vitro culture for developing cryopreservation strategies of woody plants. Acta Hortic. 1187: 177-188. doi:10.17660/ActaHortic.2017.1187.19.

Maharramova, E., Huseynova, I., Kolbaia, S., Gruenstaeudl, M., Borsch, T., and Muller, L.A.H. 2017. Phylogeography and population genetics of the riparian relict tree Pterocarya fraxinifolia (Juglandaceae) in the South Caucasus. Syst. Biodivers. 16: 14-27. doi:10.1080/14772000.2017.1333540.

Malik, S.K., and Chaudhury, R. 2010. Cryopreservation of seeds and embryonic axes of wild apricot (Prunus armeniaca L.). Seed Sci. Technol. 38: 231-235. doi:10.15258/sst.2010.38.1.24

Manchester, S.R. 1987. The fossil history of the Juglandaceae. Monogr. Syst. Bot Missouri Bot. Garden, 21: 1-137.

McIlwrick, K., Wetzel, S., Beardmore, T., and Forbes, K. 2000. Ex situ conservation of American chestnut (Castanea dentata (Marsh.) Borkh.) and butternut (Juglans cinerea L.), a review. For. Chron. 76: 765-774. doi:10.5558/tfc76765-5.

Menon, A., Funnekotter, B., Kaczmarczyk, A., Bunn, E., Turner, S., and Mancera, R.L. 2014. Cold-induced changes affect survival after exposure to vitrification solution during cryopreservation in the south-west Australian Mediterranean climate species Lomandra sonderi (Asparagaceae). Plant Cell, Tissue Organ Cult. 119(2): 347-358. doi:10.1007/s11240-014-0538-9.

Michalak, M., Plitta, B.P., Tylkowski, T., Chmielarz, P., and Suszka, J. 2015. Desiccation tolerance and cryopreservation of seeds of black poplar (Populus nigra L.), a disappearing tree species in Europe. Eur. J. For. Res. 134: 53-60. doi:10. 1007/s10342-014-0832-4

Milne, R.I., and Abbott, R.J. 2002. The origin and evolution of tertiary relict floras. In Advances in botanical research. Edited by R.D. Preston. Academic Press, Amsterdam. pp. 281-314. doi:10.1016/S0065-2296(02)38033-9.

Naqinezhad, A., Ramezani, E., Djamali, M., Schnitzler, A., and Arnold, C. 2018. Wild grapevine (Vitis vinifera subsp. sylvestris) in the Hyrcanian relict forests of northern Iran: an overview of current taxonomy, ecology and palaeorecords. J. For. Res. 29: 175. doi:10.1007/s11676-017-0549-6.

Pence, V.C. 1990. Cryostorage of embryo axes of several large-seeded temperate tree species. Cryobiology, 27: 212-218. doi:10.1016/0011-2240(90)90013-T.

Pilatti, F.K., Aguiar, T., Simões, T., Benson, E.E., and Viana, A.M. 2011. In vitro and cryogenic preservation of plant biodiversity in Brazil. In Vitro Cell. Dev. Biol. Plant, 47(1): 82-98. doi:10.1007/s11627-010-9302-y.

Popova, E.V., Kim, D.H. Han, S.H., Pritchard, H.W and Lee, J.C. 2012. Narrowing of the critical hydration window for cryopreservation of Salix caprea seeds following ageing and a reduction in vigour. CryoLetters, 33: 220-231. PMID: 22825789.

Popova, E., Moltchanova, E., Han, S.H., Saxena, P., and Du Kim, H. 2016. Cryopreservation of Prunus padus seeds. Emphasising the significance of Bayesian methods for data analysis. Can. J. For. Res. 46(6): 766-774. doi:10.1139/cjfr2016-0020.

Pritchard, H.W., Moat, J.F., Ferraz, J.B.S., Marks, T.R., Camargo, J.L.C. Nadarajan, J., and Ferraz, I.D.K. 2014. Innovative approaches to the preservation of forest trees. For. Ecol. Manage. 333: 88-98. doi:10.1016/j.foreco.2014 08.012 .

R Core Team. 2017. R: a language and environment for statistical computing [online]. R Foundation for Statistical Computing, Vienna, Austria. Available from http://www.R-project.org/.

Reed, B.M. (Editor). 2008. Plant cryopreservation: a practical guide. Springer, New York. doi:10.1007/978-0-387-72276-4.

Roberts, E.H. 1973. Predicting the storage life of seeds. Seed Sci. Technol. 1: 499-514.

Royal Botanic Gardens Kew. 2008. Seed Information Database - SID [online] Version 7.1. Available from http://data.kew.org/sid/ [accessed May 2018].

Schaarschmidt, H. 2006. Die Walnussgewächse. Juglandaceae, 3. Aufl., unveränd. Nachdr. d. 2. Aufl. Westarp Wissenschaften, Hohenwarsleben.

Suszka, B., Muller, C., Bonnet-Masimbert, M., and Gordon, A. 1996. Seeds of forest broadleaves: from harvest to sowing. INRA, Paris.

Tompsett, P.B. 1983. Handling and storage of Agathis and Araucaria seed. Silvic, 8: 290-293. 
Vertucci, C.W., and Roos, E.E. 1990. Theoretical basis of protocols for seed storage. Plant Physiol. 94: 1019-1023. doi:10.1104/pp.94.3.1019. PMID:16667791.

Walters, C. 2015. Orthodoxy, recalcitrance and in-between: describing variation in seed storage characteristics using threshold responses to water loss. Planta, 2: 397-406. doi:10.1007/s00425-015-2312-6.

Wang, B., Xu, J., Li, M., Zhao, T., and Zhang, P. 2018. Research on seed dormancy and germination characteristic of Pterocarya stenoptera seeds. For. Eng. 34(4): 11-15. [In Chinese.]

Wesley-Smith, J., Berjak, P., Pammenter, N.W., and Walters, C. 2014. Intracellular ice and cell survival in cryo-exposed embryonic axes of recalcitrant seeds of Acer saccharinum: an ultrastructural study of factors affecting cell and ice structures. Ann. Bot. 113: 695-709. doi:10.1093/aob/mct284. PMID:24368198.

Wilkinson, T. 2003. Suitability of cryopreservation for the long-term storage of rare and endangered plant species: a case history for Cosmos atrosanguineus. Ann. Bot. 91(1): 65-74. doi:10.1093/aob/mcg009. PMID:12495921.

Yilmaz, M. 2015. New locality records and conservation of Caucasian wingnut
(Pterocarya pterocarpa (Michx.) Kunth ex iiljinsk) in Southern Turkey. Anadolu Univ. J. Sci. Technol. C, Life Sci. Biotechnol. 3: 39.

Young, J.A., and Young, C.G. 1992. Seeds of woody plants in North America: revised and enlarged edition. Dioscorides Press, Portland, Ore.

Yousefzadeh, H., Rajaei, R., Fragniére, Y., and Kozlowksi, G. 2018. Genetic diversity and differentiation of the riparian relict tree Pterocarya fraxinifolia (Poir.) Spach (Juglandaceae) along altitudinal gradients in the Hyrcanian forest (Iran). In Relict woody plants: linking the past, present and future. Edited by A.K. Jasińska, A.M. Jagodziński, L. Fazan, K. Sękiewicz, and Ł. Walas. The International Scientific Conference. Kórnik 19 June 2018. Book of abstracts. Bogucki Wydawnictwo Naukowe, Poznań.

Zaritzky, N.E. 2015. The role of water in the cryopreservation of seeds. In Water stress in biological, chemical, pharmaceutical and food systems. Edited by G.F. Gutiérrez-López, L. Alamilla-Beltrán, M. del Pilar Buera, J. Welti-Chanes, E. Parada-Arias, and G.V. Barbosa-Cánovas. Springer, New York. pp. 231-244. doi:10.1007/978-1-4939-2578-0_17. 